\title{
The Multiple Layers of Environmental Injustice in Contexts of (Un)natural Disasters: The Case of Puerto Rico Post-Hurricane Maria
}

\author{
Gustavo A. García-López
}

\begin{abstract}
Hurricane Maria has had devastating impacts in Puerto Rico. Yet this catastrophe has not been felt equally by all. The vulnerability to impacts and ability to recover from hurricanes and other disasters are directly shaped by existing socioeconomic and racial inequalities. The situation post-Maria in Puerto Rico has been labeled a clear case of environmental injustice. This article documents the hurricane's nexus with environmental justice (EJ). It discusses EJ impacts related to toxic pollution, water, energy, and food, and connects these impacts intersect with multiple layers of pre-existing injustices. It then discusses how these impacts have been magnified by the national and federal government's inept and unjust responses, and by histories of unjust planning and colonial-neoliberal institutions. The article concludes with some positive outlooks of how the hurricane has also opened a window to "rethink" Puerto Rico and to self-organized initiatives for enacting a different, more just, and ecological country.
\end{abstract}

Keywords: political ecology, unnatural disasters, colonialism, just transition, Puerto Rico

\section{INTRODUCTION}

$\mathbf{O}$ N September 20, Hurricane Maria landed in Puerto Rico as a Category 4 storm with $>155 \mathrm{mph}$ winds, the strongest hurricane to hit the country in 80 years. The hurricane was destructive, but it is what happened since then which has been the real catastrophe. As I finish writing this article, 4 months after the hurricane, $40 \%$ of the population and $40 \%$ of schools still remain without electricity, $10 \%$ are still without water, between 500 and 1000 people are estimated dead, and about 500 people still await in refugee centers for relocation. The economic damages are es-

Dr. García-López is an assistant professor at Graduate School of Planning, University of Puerto Rico, Rio Piedras, San Juan, Puerto Rico. timated at between $\$ 45$ and $\$ 95$ billion, ${ }^{1}$ the already high levels of poverty have been exacerbated, ${ }^{2}$ and there has been a historic migratory wave of $\sim 200,000$ Puerto Ricans moving to the United States. ${ }^{3}$

As critical disaster and environmental justice (EJ) scholars have shown, the vulnerability to impacts and

\footnotetext{
${ }^{1}$ Joel Cintrón Arbasetti and Carla Minet. "The Dilemma of Rebuilding Puerto Rico or Paying the Debt." Center for Investigative Journalism, 17 October 2017. <http://periodismo investigativo.com/2017/10/the-dilemma-of-rebuilding-puertorico-or-paying-the-debt/>. Last accessed 17 October 2017.

${ }^{2}$ El Nuevo Día. "María aumentará el nivel de pobreza [Maria will increase the level of poverty]." El Nuevo Día, 28 November 2017.

${ }^{3}$ Caribbean Business Español. "Puerto Rico perdió 6\% de su población tras huracán María [Puerto Rico lost $6 \%$ of its population after hurricane Maria]." 9 March 2018. <http://cb.pr/ puerto-rico-perdio-6-de-su-poblacion-tras-huracan-maria $>$. Last accessed 9 March 2018.
} 
ability to recover from hurricanes and other so-called natural disasters are directly shaped by existing socioeconomic and racial inequalities, as well as by state institutions and other political-economic structures. ${ }^{4,5,6,7}$

The situation post-Maria in Puerto Rico has been labeled a clear case of environmental injustice. ${ }^{8,9}$ In contrast to the now popularized slogans such as "we are one country united" and "\#PuertoRicoSeLevanta" ("Puerto Rico rises"), it is becoming evident that the hurricane's impacts and the recovery process have not been the same for everyone. Moreover, recent reflections link this unjust disaster to Puerto Rico's historic colonial condition and related history of social and environmental exploitation. ${ }^{10,11,12}$ In these multiple ways, disasters such as Maria's are unnatural.

In this article, I delve deeper into the hurricane's nexus with EJ. I use a combination of journalistic accounts and my own participant observations as a resident in the island involved in grassroots relief and recovery efforts. The article is not intended as a research project report but as a series of critical observations. It seeks to contribute to debates about environmental injustice in the context of natural disasters, by showing its multiple layers-multiple scales (from local to global), dimensions/issues, and root causes. I document the multiple EJ impacts related to toxic pollution, water, energy, and food, and argue how these impacts intersect with pre-existing patterns of unequal distribution of harm, histories of unjust and undemocratic environmental policy and planning, and colonialneoliberal governance regimes.

${ }^{4}$ Piers Blaikie, Terry Cannon, Ian Davis, and Ben Wisner. At Risk: Natural Hazards, People's Vulnerability and Disasters. (Routledge, 2014).

${ }^{5}$ Shirley Laska and Betty Hearn Morrow. "Social Vulnerabilities and Hurricane Katrina: An Unnatural Disaster in New Orleans." Marine Technology Society Journal 40 (2006): 16-26.

${ }^{6}$ Tania López-Marrero and Ben Wisner. "Not in the Same Boat: Disasters and Differential Vulnerability in the Insular Caribbean." Caribbean Studies 40 (2012): 129-168.

${ }^{7}$ Robert Bullard. "Differential Vulnerabilities: Environmental and Economic Inequality and Government Response to Unnatural Disasters.' Social Research 75 (2007): 753-784.

${ }^{8}$ Phil McKenna. "What's Happening in Puerto Rico Is Environmental Injustice." Slate, 27 September 2017. <http://www .slate.com/articles/health_and_science/science/2017/09/puerto_rico_ is_experiencing_a_crisis_created_by_environmental_injustice .html >. Last accessed 27 September 2017.

${ }^{9}$ Vann R. Newkirk II. "Puerto Rico's Environmental Catastrophe." The Atlantic, 18 October 2017. <https://www theatlantic.com/politics/archive/2017/10/an-unsustainableisland/543207/>. Last accessed 18 October 2017.

${ }^{10}$ Pedro Cabán. "Catastrophe and Colonialism." Jacobin, December 12, 2017. <https://www.jacobinmag.com/2017/12/ puerto-rico-hurricane-maria-trump-us-status-history $>$. Last accessed 12 December 2017.

${ }^{11}$ Catalina M. de Onís. "Energy Colonialism Powers the Ongoing Unnatural Disaster in Puerto Rico." Frontiers in Communication 3 (2018): 2.

${ }^{12}$ Hilda Lloréns, Ruth Santiago, Carlos Garcia-Quijano, and Catalina M. de Onís. "Hurricane Maria: Puerto Rico's Unnatural Disaster." Social Justice Blog, 2017. <http://www .socialjusticejournal.org/hurricane-maria-puerto-ricos-unnaturaldisaster/>. Last accessed 15 December 2017.

\section{THE MULTIPLE LAYERS OF INEQUALITY AND ENVIRONMENTAL INJUSTICE IN PUERTO RICO, BEFORE AND AFTER MARIA}

EJ issues have many layers-multiple scales (from local to global), multiple dimensions/issues, and multiple roots (causes). The concept of environmental injustice refers to the inequalities in distribution of environmental harms (exposure to pollution) or goods (greenspace), the lack of real participation in decision making, and limited capabilities for autonomy. ${ }^{13,14,15}$ Environmental injustice also manifests itself through disavowing marginalized communities' political agency and livelihoods. ${ }^{16,17}$ These injustices are linked to historically enduring class, racial, and colonial structures, reproduced from local to global scales. ${ }^{18}$ Thus, as Velicu and Kaika argue, achieving EJ requires more than redistribution, participation, or recognition; it demands undoing dominant power relations and reimagining and practicing equality. ${ }^{19}$

On a large scale, Puerto Rico itself is a case of environmental injustice, considering its historic relation of "environmental colonialism" to the United States. ${ }^{20,21}$ Puerto Rico's economy and natural resources have been exploited for the benefit of U.S. corporations and the U.S. government's imperial aspirations, as evidenced by the high number of military bases and highly polluting corporations, and the Environmental Protection Agency (EPA) exceptions to federal rules. ${ }^{22}$ It has 17 superfund

${ }^{13}$ Julian Agyeman, David Schlosberg, Luke Craven, and Caitlin Matthews. "Trends and Directions in Environmental Justice: From Inequity to Everyday Life, Community, and Just Sustainabilities." Annual Review of Environment and Resources 41 (2016): 321-340.

${ }^{14}$ Isabelle Anguelovski and Joan Martínez Alier. "The 'Environmentalism of the Poor' Revisited: Territory and Place in Disconnected Glocal Struggles." Ecological Economics 102 (2014): 167-176.

${ }^{15}$ David Schlosberg. "Theorising Environmental Justice: The Expanding Sphere of a Discourse." Environmental Politics 22, (2013): 37-55.

${ }^{16}$ Irina Velicu. "Demonizing the Sensible and the 'Revolution of Our Generation' in Rosia Montana." Globalizations 12, (2015): 846-858.

${ }^{17}$ Irina Velicu and Maria Kaika. "Undoing Environmental Justice: Re-imagining Equality in the Rosia Montana Antimining Movement." Geoforum 84 (2017): 305-315.

${ }^{18}$ Laura Pulido, . "Geographies of Race and Ethnicity II: Environmental Racism, Racial Capitalism and State-Sanctioned Violence." Progress in Human Geography 41, (2017): 524-533.

${ }^{19}$ Velicu and Kaika. "Undoing Environmental Justice: Reimagining Equality in the Rosia Montana Anti-mining Movement."

${ }^{20}$ José M. Atiles-Osoria. Apuntes para abandonar el derecho: estado de excepción colonial en Puerto Rico [Notes to abandon the law: state of colonial exception in Puerto Rico]. (Editora Educación Emergente, 2016).

${ }^{21}$ Carmen M. Concepción. "El Conflicto Ambiental y Su Potencial Hacia un Desarrollo Alternativo: El Caso de Puerto Rico [The environmental conflict and its potential for an alternative development: The case of Puerto Rico]." Ambiente $y$ Desarrollo 4 (1988): 125-135.

${ }^{22}$ Concepción. "El Conflicto Ambiental y Su Potencial Hacia un Desarrollo Alternativo: El Caso de Puerto Rico [The environmental conflict and its potential for an alternative development: The case of Puerto Rico]." 
sites. More than half of the population lives under the poverty line and it remains the poorest of all U.S. territories. Colonial institutions have also significantly limited democracy, imposing a permanent state of emergency, manifested most vividly today in the PROMESA federal law and its creation of a Fiscal Control Board over the country. ${ }^{23,24}$

At a local scale, Puerto Rico has many "EJ communities," which have been subjected to environmental racism. $^{25}$ Thus, the unnatural disaster was also shaped by the different vulnerabilities to natural disasters within Puerto Rico, where everyone is "not in the same boat.",26 The effects of Maria were shaped by these pre-existing relations of injustice (within Puerto Rico and between Puerto Rico and the United States), and, as we will discuss hereunder (The State's Production of Environmental Injustice Section), by the inept responses from a collapsed state, product of decades of colonialism, and more recently neoliberal austerity and debt politics.

\section{Between no water and contaminated water}

Almost a month after the hurricane, there were still about $36 \%$ of those connected to the public water system (Puerto Rico Aqueduct and Server Authority, PRASA) without access to water; this amounted to nearly one million people. ${ }^{27}$ These numbers also showed stark ruralurban inequalities: although $80 \%$ of clients in the metropolitan area had water by that time, in the west it was only $45 \%$ and in the north $32 \% .^{28}$ By November 6 , 46 days after Maria, PRASA's website reported that $17 \%$ of clients were still without water. ${ }^{29}$ At day $70,10 \%$ of PRASA clients still did not have water. However, there were press reports in the radio about entire (rural) municipalities such as Las Piedras and Morovis, rural communities in Rio Grande municipality, and the Caimito community in San Juan where water had been lacking for weeks at a time or was at best intermittent. In Vieques, an activist explained to me in a meeting in early November

\footnotetext{
${ }^{23}$ Atiles-Osoria. Apuntes para abandonar el derecho: estado de excepción colonial en Puerto Rico [Notes to abandon the law: state of colonial exception in Puerto Rico].

${ }^{24}$ Luis J. Torres Asencio. "La Ley 76-2000 y nuestro estado permanente de emergencia [Law 76-2000 and our permanent state of emergency]." 80 grados, 17 February 2016. <http://www .80grados.net/la-ley-76-2000-y-nuestro-estado-permanente-deemergencia/>. Last accessed 17 February 2016.

${ }^{25}$ Carmen M. Concepción. "Justicia Ambiental, Luchas Comunitarias y Política Pública [Environmental Justice, Community Struggles and Public Policy]." Revista de Administración Pública 31-32 (2000): 89-113.

${ }^{26}$ Lopez-Marrero and Wisner. "Not in the Same Boat: Disasters and Differential Vulnerability in the Insular Caribbean."

${ }^{27}$ Bendery, Jennifer. "Amid Puerto Rico's Water Crisis, Unions Step in Where Trump Is Failing." Huffington Post, 23 October, 2017. <https://www.huffingtonpost.com/entry/puertorico-hurricane-maria-trump-water_us_59ee0f68e4b0a484d064c 604>. Last accessed 22 January 2018.

${ }^{28}$ El Nuevo Dia. "El estado de la isla a 21 días del huracán María. [The state of the island 21 days after hurricane Maria]" 21 October 2017. <https://www.elnuevodia.com/noticias/locales/ nota/elestadodelaislaa21diasdelhuracanmaria-2365422/>. Last accessed 21 October 2017.

${ }^{29}$ Acueductospr.com
}

that several communities had been without water for weeks. For these and other communities in rural areas, intermittent water service has always been a problem.

In the absence of well-functioning treatment plants and total lack of environmental monitoring of water quality by the government, potential contamination from water became a serious concern. As of October 16, >1 month after the hurricane, almost $40 \%$ (20 out of 51) of sewage treatment plants were not functioning. ${ }^{30}$ The hurricane's impacts on the rainwater and sanitary infrastructure led to an increase in discharges and thus water contamination. The government recommended that all water from the tap should be boiled before consumption-although most people did not have electricity to do so. In the San Juan Bay Estuary, monitoring by a federal program detected enterococci levels that are significantly higher than the norm, as well as discharges of oils and fuels; beaches and water bodies of the Estuary system were found to be in noncompliance with water quality standards. ${ }^{31}$ The same program found that two of five beaches in the Estuary did not meet water quality levels. In mostly rural areas, such as the town of Juncos in the southeast, thousands of residents without water were bathing, washing clothes, and even drinking from places potentially contaminated by these untreated waters. ${ }^{32}$ The use of these water bodies, the damaged houses, and the mounting trash led to another problem: an outbreak of leptospirosis (bacteria transmitted by rat urine), which has killed several people. In the coastal town of Dorado, people were so desperate for water that they took it from wells that had been closed by the EPA because of contamination. ${ }^{33}$

\section{Between dirty energy and no energy}

Energy production and distribution in Puerto Rico have been in crisis for at least a decade. The public utility (Puerto Rico Electric Power Authority, PREPA) has $>7$ billion U.S.D in debt due to decades of mismanagement. The money borrowed did not translate into a modern and robust infrastructure, nor to a diversification of sources. Ninety-eight percent of energy production comes from

${ }^{30}$ David Leonhardt. "Puerto Rico's Crisis by the Numbers." New York Times, 17 October 2017. <https://www.nytimes.com/ 2017/10/17/opinion/puerto-ricos-crisis-by-the-numbers.html?rref= collection\%2Ftimestopic\%2FPuerto\%20Rico>. Last accessed 17 October 2017.

${ }^{31}$ El Nuevo Día. "La calidad del agua del Estuario de la Bahía de San Juan retrocede [The water quality of the San Juan Bay Estuary recedes]." 11 November, 2017. <http://www.elnuevodia .com/noticias/locales/nota/lacalidaddelaguadelestuariodelabahiad esanjuanretrocede-2373742/>. Last accessed 11 November 2017.

${ }^{32}$ Univision. "Miles de puertorriqueños toman agua contaminada y se bañan en ella por falta del servicio tras el paso del huracán María [Thousands of Puerto Ricans drink contaminated water and bathe in it due to lack of service after hurricane Maria's passing]." 18 October, 2017. <http://www.univision.com/ puerto-rico/wlii/noticias/huracan-maria/miles-de-puertorriquenostoman-agua-contaminada-y-se-banan-en-ella-por-falta-del-serviciotras-el-paso-del-huracan-maria>. Last accessed 18 October 2017.

${ }^{33}$ Univision. "Miles de puertorriqueños toman agua contaminada y se bañan en ella por falta del servicio tras el paso del huracán María [Thousands of Puerto Ricans drink contaminated water and bathe in it due to lack of service after hurricane Maria's passing]." 
fossil fuels produced in large and outdated facilities that then transmit it across the whole island through aboveground lines. ${ }^{34}$ The historical evolution of energy production is linked to a history of "energy colonialism.", 35

Maria knocked out $80 \%$ of these poorly maintained transmission lines-about 55,000 electric poles and 6500 lines of cable-leaving $100 \%$ of citizens without electricity. The geographic pattern of the return to electricity has shown a tendency to focus on the metropolitan area, which is where most population in the country lives, but is also the wealthiest region. The Condado neighborhood, the wealthiest in San Juan, was the first area to receive electricity in the whole island. As of mid-December, power was restored to $65 \%$ of production capacity (which does not equal $65 \%$ of citizens), and nine municipalities still had zero electricity. ${ }^{36}$ Other municipalities had minimal connection, such as Humacao, which only had its hospital energized, or Vega Baja, which only had $10 \%$ electricity. The map in PREPA's website showed these were located in the central mountainous and southeastern regions, the poorest of the country and the hardest hit by the hurricane. ${ }^{37}$ Within San Juan, there were also differences based on wealth: the poorest communities, such as those in the Caño Martín Peña region, were still without electricity as of mid-December.

In this context, citizens have turned to the widespread use of backup electric generators - an estimated 100,000 were in operation as of mid-November, ${ }^{38}$ leading some to call Puerto Rico "Generator Island." 39 Wealth strongly shaped the ability to have and operate these generators. After the hurricane, residents from Condado I talked to explained they never lost electricity because they had huge backup electricity generators, which provided all of the amenities including centralized air conditioning, and cost dozens of thousands of dollars to run each week. In contrast, residents

${ }^{34}$ INESI-Instituto Nacional de Energía y Sostenibilidad Isleña. Estado de Situación Energética de Puerto Rico-Informe Anual 2015 [State of the Energy Situation of Puerto Rico - Annual Report 2015]. (Oficina de Política Pública Energética, Gobierno de Puerto Rico, 2015).

${ }^{35}$ de Onís. "Energy Colonialism Powers the Ongoing Unnatural Disaster in Puerto Rico."

${ }^{36}$ El Nuevo Dia. "Rosselló culpa de nuevo al USACE por tardar en reparar la red energética [Roselló blames USACE again for delaying to repair the electricity grid]." 18 December, 2017. $<$ https://www.elnuevodia.com/noticias/politica/nota/rossellocul padenuevoalusaceportardarenrepararlaredenergetica-2383260/ \#cxrecs_s>. Last accessed 18 December 2017.

${ }^{37}<$ http://status.pr/Maps/Map/AEE $>$. Last accessed 15 December 2017.

${ }^{38}$ Damaris Suarez. "Agencias de gobierno no actúan ante peligros que conllevan los generadores eléctricos [Government agencies do not act on dangers from electric generators]." Centro de Periodismo Investigativo, 13 November 2017. <http://period ismoinvestigativo.com/2017/11/agencias-de-gobierno-no-actuanante-peligros-que-conllevan-los-generadores-electricos/>. Last accessed 13 November 2017.

${ }^{39}$ Ruth Santiago. "Reflections on the Power Grid Debate, 'Generator Island' and the Telecommunications Failure in Puerto Rico." Latino Rebels, 15 , October 2017. <http://www .latinorebels.com/2017/10/15/reÓections-on-thepower-griddebate-generator-island-and-the-telecommunications-failureinpuerto-rico>. Last accessed 15 October 2017. of poor neighborhood could not afford a generator or if they did, it was of limited capacity that they could use only minimally. In the context of a government "emergency decree" removing regulations for the operation of generators, their excessive use has become a significant air and noise pollution, health problems, and source of intracommunity conflict. Doctors alerted about their observed increase in cases of respiratory illnesses after Maria: these have been aggravated by the government's lack of planning, coordination, and education between agencies; lack of sufficient personnel to attend citizen complaints; and lack of monitoring by the state and federal agencies. ${ }^{40}$

\section{Flying coal ash and toxic flooding}

The concerns about energy production relate to longstanding environmental injustice conflicts in the south of Puerto Rico. A main issue has been the coal ash produced by the Applied Energy Systems (AES) coal power plant in the southern town of Guayama, located next to a lowincome and minority community of 45,000 people. A recent analysis showed that in 2015 , the country generated $15,166,481$ metric tons of $\mathrm{CO}_{2}\left(4.37 \mathrm{~m}^{3}\right.$ per capita), of which $76.6 \%(11,623,118)$ were generated in this region, with the AES plant being the second highest emitter in the country. ${ }^{41}$ Since it started operations in the 1990s, AES has been disposing the ashes illegally throughout marginalized communities of the south region. Although the ash is not considered a hazardous waste by the EPA, multiple studies have confirmed its toxic composition with heavy metals such as arsenic, mercury, and chromium, whereas health studies show high rates of health problems in the region. ${ }^{42}$

For the past year, AES has illegally stored a giant fivefloor high mountain of hundreds of thousands of tons of coal ash in its premises, raising concerns about fugitive ash. ${ }^{43}$ Before hurricane Irma and again before Maria, the government's Environmental Quality Board, after pressure from community activists, required that AES cover the mountain; in both occasions AES refused, putting nearby residents in danger. Pictures from a local newspaper showed that the mountain had become eroded and cracked. ${ }^{44} \mathrm{~A}$ resident said

\footnotetext{
${ }^{40}$ Suarez. "Agencias de gobierno no actúan ante peligros que conllevan los generadores eléctricos [Government agencies do not act on dangers from electric generators]."

${ }^{41}$ INESI. Estado de Situación Energética de Puerto RicoInforme Anual 2015 [State of the Energy Situation of Puerto Rico - Annual Report 2015].

${ }^{42}$ Ruth Santiago. "Imminent and Substantial Endangerment to Human Health and the Environment from Use of Coal Ash as Fill Material at Construction Sites in Puerto Rico: A Case Study." Procedia-Social and Behavioral Sciences 37 (2012): 389-396.

${ }^{43}$ The contract of AES with the Electric Power Authority prohibited that AES store the ash for more than 180 days in its premises; the environmental permit given to the AES further established, per the company's own plans, that the ash could not be deposited anywhere in Puerto Rico.

${ }^{44}$ Jason Rodriguez and Omar Alfonso. "Huracán María desgastó y agrietó montaña de cenizas en Guayama [Hurricane Maria wore down and cracked the ash mountain in Guayama]." La Perla del Sur, 5 October 2017. <http://www.periodicolaperla .com/huracan-maria-desgasto-agrieto-montana-cenizas-guayama/>. Last accessed 5 October 2017.
} 
he was more worried about the ash than about having lost his roof. ${ }^{45}$ To date the results of an EPA investigation on this have not been released. The state's Environmental Quality Board, for its part, took 1 month to send a team to investigate how the mountain of coal ash may have dispersed into and polluted nearby residential areas, water bodies, and other ecosystems; the findings from this inspection have not been made public. ${ }^{46}$ To add to this injustice, the communities next to this power plant and to the ashes do not receive any of this electricity and indeed are, after $>4$ months, among those still without electricity.

Communities next to superfund sites, petrochemical facilities, and other toxic storage facilities may be at particular risk from flooding caused by Hurricane Maria, ${ }^{47}$ as was starkly demonstrated with the case of Harvey in Texas, where dozens of industrial facilities and superfund sites spilled toxic wastes. ${ }^{48,49}$ One month after the hurricane, 5 of 18 toxic-waste sites in Puerto Rico had not been inspected to assess potential toxic spillovers; the EPA claimed it had not been able to send personnel. ${ }^{50}$ The results of those inspected have not been made public to date.

\section{Eating whatever food the ships bring}

An old saying in Puerto Rico, popular during the crisis period of the $1930 \mathrm{~s}$ after Hurricane San Felipe, was that one had to eat "whatever the ship brought." Our strong dependency on imported food today-about $85 \%$ of all food consumed-has for years been pointed out as a source of extreme vulnerability for food security, especially considering climate change and its impacts on transportation infrastructure. ${ }^{51}$ This dependency also has negative impacts on health-much food is canned or not truly "fresh" and has high pesticide content. It also has a significant impact on household and national economy: due to the embargo imposed by the U.S. Jones Act, food in Puerto Rico costs

\footnotetext{
${ }^{45}$ Univision. "Miles de puertorriqueños toman agua contaminada y se bañan en ella por falta del servicio tras el paso del huracán María [Thousands of Puerto Ricans drink contaminated water and bathe in it due to lack of service after hurricane Maria's passing]."

${ }^{46}$ Jason Rodriguez. "¿Excusas? Reclaman a la JCA rendir cuentas sobre montaña de cenizas [Excuses? JCA is demanded to offer explanations about the ash mountain]." La Perla del Sur 2 November 2017.

${ }^{47}$ McKenna. "What's Happening in Puerto Rico Is Environmental Injustice."

${ }^{48}$ Van R. Newkirk II. "The Looming Superfund Nightmare." The Atlantic, 12 September 2017. <https://www.theatlantic.com/ health/archive/2017/09/the-looming-superfund-nightmare/539316/>. Last accessed 12 September 2017.

${ }^{49}$ Sammy Roth. "Hurricane Harvey floodwaters brimming with raw sewage, toxic chemicals." The Desert Sun, 5 September 2017. <https://www.usatoday.com/story/weather/2017/ 09/05/hurricane-harvey-floodwaters-brimming-raw-sewage-toxicchemicals/632937001/>. Last accessed 5 September 2017.

${ }^{50}$ Leonhardt. "Puerto Rico's Crisis by the Numbers."

${ }^{51}$ Myrna Comas. Vulnerabilidad de las cadenas de suministros de alimentos de Puerto Rico, el cambio climático y estrategias de adaptación [Vulnerability of the chain of food supply in Puerto Rico, climate change and strategies of adaptation]. (University of Puerto Rico, Mayagüez, 2010).
}

about $25 \%-30 \%$ more than what it should. ${ }^{52}$ In this context, Maria created an immediate food shortage crisis, which had been predicted by many but for which there was no clear plan implemented. The Jones Act-a symbol of our colonial condition - ${ }^{53}$ furthered this crisis, as it delayed delivery of food and other aid to the island.

When a few supermarkets began to open in the metropolitan area a few days after the hurricane, long lines and some chaos formed. The multiple layers of injustice ran much deeper than the lines at the supermarket. Some people in the line had a salary that kept flowing, others did not have such a good salary, or had lost their job (as thousands did). Thousands others had to use food stamps, but they were not being accepted in many supermarkets because "they did not have the system up," as I later learned from a friend who struggled to find a place that accepted her card. People in rural areas, who in Puerto Rico are poorer, were hardest hit. Many could not even go to the supermarket, because there was none or their roads were blocked.

Press reports confirmed that aid was not reaching the mountain areas. Two weeks after the hurricane, an interviewee who came from the United States to visit his sister and bring supplies to her "described pregnant women and children chasing his car, believing he was with FEMA, begging for food and water." He said: "We are a family with resources. If my sister is going through this, what about others?" 54 The reporter continued describing the everyday basic life crisis faced near the rural towns of Yabucoa and San Lorenzo, just northwest of where Maria made landfall: "Which lifesaving line should they stand in today? A line for medicine? A line for gas? A line for cash? A line for food and water? And where, they wonder, can they even find food and water?"

On October 11, FEMA officials admitted their concern about a huge food shortage in the island: it was allegedly providing 200,000 meals a day, but there was a shortfall of 2 million meals a day. ${ }^{55}$ These images contrasted sharply with those in the Condado neighborhood only 3 weeks after the hurricane, where I saw live music and people happily drinking and eating, powered by massive generators in my daily visits to a hotel to use my computer. ${ }^{56}$ Apparently, the temporary alcohol prohibition in effect at the time in the whole country did not seem to apply to rich people, federal agents, and tourists; even the right to have

\footnotetext{
${ }^{52}$ The Act requires all imports to Puerto Rico to use U.S. ships, the most expensive in the world.

3 de Onís. "Energy Colonialism Powers the Ongoing Unnatural Disaster in Puerto Rico."

${ }^{54}$ CNBC. "'I'm So Hungry.' Deep in Puerto Rico's Countryside, We See Firsthand the Post-Maria Crisis." 3 October 2017. <https://www.cnbc.com/2017/10/03/im-so-hungry-deep-inpuerto-ricos-countryside-we-see-firsthand-the-post-maria-crisis .html >. Last accessed 3 October 2017.

${ }^{55}$ The Guardian. "Puerto Rico: US Officials Privately Acknowledge Serious Food Shortage." 11 October 2017. <the guardian.com/world/2017/oct/11/puerto-rico-food-shortagehurricane-maria>. Last accessed 11 October 2017.

${ }^{56}$ CNBC. "'I'm So Hungry.' Deep in Puerto Rico's Countryside, We See Firsthand the Post-Maria Crisis."
} 
fun was restricted to certain privileged groups. Scarcity of water, energy, and food was clearly based on wealth.

Compounding this situation, Maria destroyed about $80 \%$ of the crops in Puerto Rico. ${ }^{57}$ Almost the entire plantain and banana crops were lost, about $50 \%$ of the coffee crops, $>2$ million poultry, and thousands of cows. This means that the percentage of food imported is likely to have increased to about $97 \%$ (20\% of $15 \%$, i.e., $3 \%$ being produced locally). The losses are estimated at \$200 million in crop damages and $\$ 1.8$ billion in related infrastructure (plus \$45 million from hurricane Irma). This is likely to increase prices and exacerbate food shortages on the island. It is also likely to mean a worsened diet and health, more dependent on highly salty and canned products.

\section{THE STATE'S PRODUCTION OF ENVIRONMENTAL INJUSTICE}

State policies and actions previous to, during, and after disasters tend to reproduce inequalities. ${ }^{58,59}$ The UN High Commissioner on Human Rights, ${ }^{60}$ concluded that Puerto Rico remained in an alarming situation and without an effective emergency response more than a month after Hurricane Maria. In Puerto Rico, a popular saying among commentators and activists in this period has been that "hurricanes are natural, but disasters are political." Government lack of preparation and planning at local, state, and federal levels has been identified by journalistic investigations and expert assessments. ${ }^{61,62,63,64}$

At the local level, the government did not follow its own hurricane disaster preparedness and response plans,

${ }^{57}$ New York Times. "Puerto Rico's Agriculture and Farmers Decimated by Maria." 24 September, 2017. <https://www .nytimes.com/2017/09/24/us/puerto-rico-hurricane-maria-agriculture.html?_r=1>. Last accessed 24 September 2017.

${ }^{58}$ Timothy W. Collins. "Marginalization, Facilitation, and the Production of Unequal Risk: The 2006 Paso del Norte Floods." Antipode 42 (2010): 258-288.

Ben Wisner. "Risk and the Neoliberal State: Why PostMitch Lessons Didn't Reduce El Salvador's Earthquake Losses." Disasters 25 (2001): 251-268.

${ }^{60}$ OHCHR-UN Office of the High Commissioner on Human Rights. "Puerto Rico: Human Rights Concerns Mount in Absence of Adequate Emergency Response." 30 October, 2017. $<$ http://www.ohchr.org/EN/NewsEvents/Pages/DisplayNews.aspx ?NewsID=22326\&LangID=E $>$. Last accessed 30 October 2017.

${ }^{61}$ Stephen Collinson. "Trump White House feels heat on Puerto Rico." CNN Politics, 29 September, 2017. <http:// edition.cnn.com/2017/09/29/politics/president-donald-trumppuerto-rico-hurricane-politics/index.html>. Last accessed 29 September 2017.

${ }^{62}$ Tim Dickinson. "Puerto Rico Is Becoming Trump's Katrina." Rolling Stone, 26 September 2017. <http://www.rolling stone.com/politics/features/how-puerto-rico-is-becoming-trumpskatrina-w505523>. Last accessed 26 September 2017.

${ }^{63}$ El Nuevo Día. "El Gobierno no usó su plan catastrófico [The government did not use its plan for catastrophes]." 15 November 2017.

${ }^{64}$ Omaya Sosa Pascual and Patricia Mazzei. "Huracán María: dónde falló el operativo de respuesta [Hurricane Maria: Where the response operation failed]." Centro de Periodismo Investigativo, 22 October 2017. <http://periodismoinvestigativo .com/2017/10/huracan-maria-donde-fallo-el-operativo-de-respuesta/>. Last accessed 22 October 2017. the response was poorly coordinated, and the state agency in charge of emergency management was sidelined in the decision-making process. ${ }^{65}$ Reports pointed out that PREPA did not have the materials needed for the repairs (e.g., poles), which had not been ordered on time, ${ }^{6,67}$ and that PREPA employees were corruptly charging thousands of dollars for a "speedier" connection. ${ }^{68}$ The Whitefish scandal and the multiple delays in repairing the electric grid are further evidence of ineptitude and also corruption. Civil society and political opposition leaders have argued that regions where the ruling party has majority support are being given preference in the repairs.

At the federal level, 1 month after the hurricane, FEMA had distributed 6.2 million gallons of bottled and bulk water, which equaled only $9 \%$ of the island's drinking water requirement per the WHO guidelines. ${ }^{69}$ The food distributed was also grossly insufficient even for those receiving it, per FEMA's own admissions. A friend from a rural community in Humacao posted a picture of the food she was given by FEMA 2 weeks after Maria: a bag with two small bottles of water, a can of Virginia sausages, a Nutri-Grain bar, and a pack of tropical Skittles. By that time (mid-October), the agency had distributed 38,000 tarps-not even one-sixth of the estimated 200,000 affected roofs. ${ }^{70}$

When questioned about why aid was not reaching many places, a FEMA spokesperson gave the incredulous explanation that they were impossible to reach, only to be refuted by evidence by a press group who went the next day to those same areas claimed by FEMA to be inaccessible. For the first critical week posthurricane, the ports were full of containers waiting to be transported to supermarkets and other locations, but inexplicably could not get out-apparently hoarded by FEMA. ${ }^{71}$ There are

${ }^{65}$ El Nuevo Día. "El Gobierno no usó su plan catastrófico [The government did not use its plan for catastrophes]."

${ }^{66}$ Primera Hora. "Se va con el corazón roto y sin resolver [He leaves with his heart broken and without resolving]." 23 November, 2017. <http://www.primerahora.com/noticias/puerto-rico/nota/ sevaconelcorazonrotoysinresolver-1256856/>. Last accessed 23 November 2017.

${ }^{67}$ El Nuevo Dia. "Rosselló culpa de nuevo al USACE por tardar en reparar la red energética. [Roselló blames USACE again for delaying to repair the electricity grid]"

${ }^{68}$ Primera Hora. "El chanchullo para conectar la luz abarca diversos pueblos [The corruption to connect the electricity is spread through several towns]." 22 November 2017. <http:// www.primerahora.com/noticias/gobierno-politica/nota/elchanchull oparaconectarlaluzabarcadiversospueblos-1256633/>. Last accessed 22 November 2017

${ }^{69}$ Mathew Rozsa. "Puerto Rico's Governor Begs: 'We Need Equal Treatment' from FEMA." Salon, 19 October 2017. <https:// www.salon.com/2017/10/19/puerto-ricos-governor-begs-we-needequal-treatment-from-fema/>. Last accessed 19 October 2017.

${ }^{70}$ Rozsa. "Puerto Rico's Governor Begs: 'We Need Equal Treatment' from FEMA."

${ }^{71}$ El Nuevo Día. "Miles de vagones con mercancía permanecen en los muelles [Thousands of wagons with merchandise remain in the docks]." 25 September, 2017. <https://www .elnuevodia.com/noticias/locales/nota/milesdevagonesconmer canciapermanecenenlosmuelles-2360301/>. Last accessed 25 September 2017. 
widespread reports that relief aid and federal disaster funds have been embezzled by local and state government officials and are being distributed through clientelistpartisan logics, and the FBI has anticipated arrests. ${ }^{72}$ For its part, the state government blamed the U.S. Corps of Engineers' slow bureaucracy in the delays in repairing the energy grid. $^{73}$

In Puerto Rico, the lack of preparedness was combined with a lack of financial resources due to a historic economic crisis, a systemic lack of infrastructural investment and maintenance, and an enormous fiscal deficit ( $\$ 74$ billion in debt)—itself the product of decades of failed economic policies and possibly corruption. ${ }^{74}$ The OHCHR report $^{75}$ emphasized that the hurricane has aggravated the island's existing dire poverty and human rights situation caused by debt and neoliberal austerity measures. In the case of the federal government, there was an obvious unequal treatment in comparison with U.S. states, related to the condition of Puerto Rico as "second-class" colonial citizens. The OHCHR observed "the dissimilar urgency and priority given to the emergency response in Puerto Rico, compared to the U.S. states affected by hurricanes in recent months." For instance, FEMA has only deployed 1700 personnel to Puerto Rico and the Virgin Islands since Maria, whereas it sent 2600 personnel to the Gulf Coast after Harvey. ${ }^{76}$

The unequal slowness was also evident in the authorization of reconstruction aid to repair Puerto Rico's infrastructure. One month after the hurricane, this aid had not been approved for Puerto Rico, but it had already been approved for the U.S. Virgin Islands, and it took 10 days to be approved for Texas post-Harvey. ${ }^{77}$ President Trump's visit clearly evidenced this colonial disdain: only 3 weeks after the hurricane, he complained that we were "throwing the U.S. budget out of whack," tweeted that he could not keep FEMA and other federal officials in PR "forever," and that were ungrateful and wanted "everything done for us."

The EJ issues were compounded by injustices and undemocratic procedures in land-use planning and environmental regulation. As in the case of New Or-

\footnotetext{
${ }^{72}$ Noticel. "FBI anticipa arrestos en la isla por fondos federales post María [FBI anticipates arrests in the island for federal funds post-Maria]." 27 December 2017. <http://www.noticel.com/ ahora/fbi-anticipa-arrestos-en-la-isla-por-fondos-federales-postmaria/678147437>. Last accessed 27 December 2017.

${ }^{73}$ El Nuevo Dia. "Rosselló culpa de nuevo al USACE por tardar en reparar la red energética [Roselló blames USACE again for delaying to repair the electricity grid]."

${ }^{74}$ Heriberto Martínez-Otero and Ian Seda-Irizarry. "The Origins of the Puerto Rican Debt Crisis." Jacobin, 10 August 2015.

${ }^{75}$ OHCHR. "Puerto Rico: Human Rights Concerns Mount in Absence of Adequate Emergency Response."

${ }^{76}$ Rozsa. "Puerto Rico's Governor Begs: 'We Need Equal Treatment' from FEMA."

${ }^{77}$ Vox. "FEMA Has Yet to Authorize Full Disaster Help for Puerto Rico." 16 October 2017. <https://www.vox.com/policyand-politics/2017/10/3/16400510/fema-puerto-rico-hurricane>. Last accessed 16 October 2017.

${ }^{78}$ Laska and Morrow. "Social Vulnerabilities and Hurricane Katrina: An Unnatural Disaster in New Orleans."
}

leans after Katrina ${ }^{78}$ and Florida after Irma, ${ }^{79}$ ongoing analyses underscore how the government's planning has "magnified" the disaster, promoting urbanization in areas highly vulnerable to flooding, landslides, coastal erosion, and storm surges, while weakening environmental legislation and developing "fast-track" permitting processes. ${ }^{80}$ Historically, these actions have been taken without regard for the affected communities. ${ }^{81}$ As of $2010,342,000$ people lived in floodways or coastal areas subject to storm surges, and $49 \%$ of the population lived in areas susceptible to landslides. ${ }^{82}$ Many of those living in these areas are lowincome communities. These impacts are ultimately related to climate justice: while the less-wealthy countries such as Puerto Rico have contributed least to climate change, they will bear the biggest impacts. ${ }^{83}$ Our hundreds of thousands of migrants are indeed "climate refugees."

Lastly, these unjust outcomes are framed in a context of a history of environmental colonialism, as reflected most clearly in the Jones Act, PROMESA Act, FEMA's unequal treatment after the hurricane, and the history of imposed environmentally destructive and unjust industrialization called "Operation Bootstrap.",84,85,86,87

\section{CONCLUSIONS}

This article has documented some of the many layers of environmental injustice that existed previous to, and were magnified by, Hurricane Maria in Puerto Rico. It focused on issues of toxic pollution, water, energy, and food, and their distributional inequalities; it linked these inequalities to historical patterns of unequal environmental policy and planning, colonialism, corruption, and neoliberal austerity. These structural conditions are arguably the real disaster in the country. Furthermore, these patterns are likely to worsen as

\footnotetext{
${ }^{79}$ Annie Sneed. "Hurricane Irma: Florida's Overdevelopment Has Created a Ticking Time Bomb." Scientific American, 12 September 2017. <https://www.scientificamerican.com/article/ hurricane-irma-floridas-overdevelopment-has-created-a-tickingtime-bomb/>. Last accessed 12 September 2017.

${ }^{80}$ Luis Jorge Rivera Herrera. "El gobierno magnifica los desastres [The government magnifies disasters]." El Nuevo Día, 15 September 2015

${ }^{81}$ Concepcion. "Justicia Ambiental, Luchas Comunitarias y Política Pública [Environmental Justice, Community Struggles and Public Policy]."

${ }^{82}$ McKenna. "What's Happening in Puerto Rico Is Environmental Injustice."

${ }^{83}$ J. Timmons Roberts "The International Dimension of Climate Justice and the Need for International Adaptation Funding." Environmental Justice 2 (2009): 185-190.

${ }^{84}$ Atiles-Osoria. Apuntes para abandonar el derecho: estado de excepción colonial en Puerto Rico [Notes to abandon the law: state of colonial exception in Puerto Rico].

${ }^{85}$ Cabán. "Catastrophe and Colonialism."

${ }^{86}$ de Onís. "Energy Colonialism Powers the Ongoing Unnatural Disaster in Puerto Rico."

${ }^{87}$ Lloréns et al.. "Hurricane Maria: Puerto Rico's Unnatural Disaster."
} 
climate change advances. The tragedy is that the forms of governance needed to redress these injusticesmore ecological and democratic, and nonextractivistare inherently at odds with the neoliberal-colonialist project. $^{88}$

Not everything in the aftermath of Maria, however, has been negative. The hurricane provided a "wake-up" call, a visibilization of poverty, environmental injustice, and the differential vulnerability to disasters. This has opened a debate for the need for a transformation of the country based on social justice, direct democracy, and sustainability. This has included calls for eliminating the debt ${ }^{89}$ and the Jones Act, and the need to rethink our energy system. Casa Pueblo, a longstanding grassroots environmental organization, has developed a campaign called \#50consol, which proposes to produce $50 \%$ of our energy with renewables, mainly solar. The "Our Power Campaign," developed by the U.S.-based Climate Justice Alliance, has given international visibility to these issues under the banner of a "just recovery and transition" planned democratically, as well as to the need for increased food sovereignty through agroecological prac- tices. $^{90}$ The hurricane has also fostered community building, as evidenced by the dozens of community initiatives across the country that have filled the response gap that the state left, including "social kitchens" and community-led aid distribution, health clinics, and psychological and educational activities. These initiatives give hope that there can be progress toward a just transition in Puerto Rico.

\section{AUTHOR DISCLOSURE STATEMENT}

No competing financial interests exist.

Address correspondence to:

Gustavo A. Garcia-Lopez.

Graduate School of Planning

University of Puerto Rico, Rio Piedras

PO Box 23354

San Juan 00931-3354

Puerto Rico

E-mail: gustavo.garcia9@upr.edu

\footnotetext{
${ }^{88}$ Naomi Klein. This Changes Everything: Capitalism versus the Climate. (New York: Simon \& Schuster, 2017).

${ }^{89}$ Rafael Bernabe. "Algunas lecciones del huracán [Some lessons from the hurricane]." 80 grados, 6 October 2017. $<$ http://www.80grados.net/algunas-lecciones-del-huracan/>. Last accessed 6 October 2017.

${ }^{90}$ Elizabeth Yeampierre and Naomi Klein. "Imagine a Puerto Rico Designed by Puerto Ricans." The Intercept, 20 October 2016. <https://theintercept.com/2017/10/20/puerto-rico-hurricanedebt-relief/>. Last accessed 20 October 2017.
} 